\title{
Effect of whole body extremely high frequency electromagnetic irradiation exposure on lipid peroxidation in rats
}

\section{Gayane Poghosyan*,}

\section{Marieta Mikaelyan,}

\section{Anahit Nerkararyan,}

\section{Poghos Vardevanyan}

Department of Biophysics, Faculty of Biology,

Yerevan State University,

1 Alex Manoogian St.,

Yerevan 0025, Armenia
Background. Electromagnetic irradiation with extremely high frequencies (EHF EMI) and low intensity affects living organisms of a different level of organization, but the mechanism(s) of its influence is still not understood well. This study was undertaken to examine the effects of EHF EMI on tissue lipid peroxidation (LPO) of whole body exposure rats.

Material and methods. Male Wistar rats were selected for this study. The animals were divided into two groups: sham exposed and experimental. The rats were exposed to the EMI of 42.2 and $50.3 \mathrm{GHz}$ frequencies (power density $0.06 \mathrm{~mW} / \mathrm{cm}^{2}$ ) for $20 \mathrm{~min} /$ day, for five days. The content of malondialdehyde (MDA) as the final product of the LPO was estimated in brain, liver, heart, and skeletal muscle of rats.

Results. Treatment with EMI induced oxidative stress in different organs of the rats, which was indicated by the changes of MDA level depending on the EMI frequency used and exposure duration. The MDA rate shows significant increase in brain $(P<0.001)$ depending on the treatment duration for both EMI frequencies used. The slightly elevated levels of MDA in the liver were observed among rats in $50.3 \mathrm{GHz}$ frequency EMI-exposed group. Concerning the skeletal muscle and especially the cardiac tissue, the MDA values remained at the same levels in experimental and control groups and did not differ significantly.

Conclusions. The EHF EMI applied in the multiple mode significantly enhanced the lipid peroxidation level in the brain and slightly increased the same parameter in liver. The obtained data indicate possible health implications of such exposures, which may cause damage in brain.

Keywords: extremely high frequency electromagnetic irradiation, oxidative stress, lipid peroxidation, malondialdehyde, rats

\footnotetext{
*Corresponding author. Email: g.poghosyan@ysu.am
} 


\section{INTRODUCTION}

Extremely high frequency (EHF) electromagnetic irradiation (EMI) (a range from 30 to $300 \mathrm{GHz}$ ), or low-intensity millimetre waves (MMW) induces changes in living organisms of a different level of organization. The absence of coherent irradiation of this range from natural electromagnetic environment might have made this band convenient for inter- and intracellular communications (Pokhomov et al., 1998; Ongel et al., 2009). Nowadays, MMW technologies are being increasingly used in wireless communication, traffic and military radar systems, which makes the investigation into the influence of EHF irradiation on living matter very important.

Moreover, MMWs are widely used for different medical applications, alone or in combination with other means, against a variety of neurological, cardiovascular, gastroenterological and skin diseases (Betskii, Lebedeva, 2004; Vecchia et al., 2009). Specifically, the most common frequencies used in therapy are 35, 42.2, 53.6, 61.2, and $78 \mathrm{GHz}$ (Betskii, Lebedeva, 2004). Interacting with the cellular system, the EHF EMI energy does not destroy inter-atomic bounds, because it is lower than the activation energy needed for different physical-chemical phenomena such as splitting covalent and hydrogen bounds (Sinitsyn et al., 2000; Betskii et al., 2004). However, EMI energy can be stored by molecular dipole vibration mode. The MMW energy of current medical applications is generally in low power levels (up to $10 \mathrm{~mW} / \mathrm{cm}^{-2}$ ) and is considered as non-thermal exposure (Pokhomov et al., 1998; Betskii et al., 2004). However, the specific mechanisms of EHF EMI-induced biological effects are insufficiently studied.

Recently it has been shown that MMWs with frequencies 50.3, 51.8, and $65 \mathrm{GHz}$ (wavelength $5.96 \mathrm{~mm}, 5.79 \mathrm{~mm}$, and $4.6 \mathrm{~mm}$ ) correspond to water cluster structure vibrations or resonant frequencies in which the biological effects are more pronounced (Sinitsyn et al., 2000). It is supposed that MMWs of resonant frequencies are capable of changing the structure and properties of water component of cells, and of influencing the conformation of biomolecules, responsible for biochemical reactions (Betskii et al., 2004).

At the same time, the majority of researchers believe that all membranes of different objects serve as the main location of influence for radiation in MM-range: primary mechanisms which determine the final effect of radiation in MM-range influence are developed in the membranes (Moustafa et al., 2001; Ramundo-Orlando, 2010; Torgomyan, Trchounian, 2012). It has been suggested that EMI leads to changes in membrane properties: to acceleration or suppression in the transport of active ions, to changes in the permeability of biological membranes due to proteins conformation changes and by means of membrane lipid peroxidation (LPO) (Sharov et al., 1983; Martinyuk, Temur'yants, 1995; Potselueva et al., 1998). The latter may be the consequence of an increased production of reactive oxygen species (ROS) (Vladimirov, Archakov, 1972; Halliwel, Gutteridge, 1999). The cell membrane, which is composed of poly-unsaturated fatty acids, is a primary target of an ROS attack leading to cell membrane damage. Animals and plants have developed various protective mechanisms to eliminate or reduce ROS, such as an antioxidant system composed of both enzymatic (superoxide dismutase (SOD), catalase (CAT), peroxidase (POX), and non-enzymatic (glutathione, ascorbic acid, tocopherol, and carotenoids) antioxidants (Halliwel B., Gutteridge 1999; Repetto et al., 2010). The equilibrium between the production and the scavenging of ROS may be disturbed by the stress factor.

In recent years there have been publications which provide information about a variety of shifts in the lipid peroxidation processes and the function of the antioxidant system of the organism during a MMW exposure (Ovoshchnikova et al., 2001; Devrim et al., 2008, Savin et al., 2010).

It has been suggested by Cojocaru et al. (Cojocaru et al., 2005) that the activation of lipid peroxidation could be a possible cause of the increase in electrical conductivity of membranes induced by MMW radiation.This assumption was supported by early data (Sharov et al., 1983; 
Potselueva et al., 1998) on a 20-30\% increase of lipid peroxidation products in $15 \mathrm{~min}$ after exposure of liposome samples to $42-64 \mathrm{GHz}$ radiation, at $0.15-1 \mathrm{~mW} / \mathrm{cm}^{2}$. On the other hand, no effect on lipid peroxides formation was reported by Logani and Ziskin (Logani, Ziskin, 1996) that exposed liposomes to MMW at 53.6; 61.2 and $78.2 \mathrm{GHz}$ frequencies. Changes in the activity of catalase, superoxide dismutase, and MDAcontent were reported by Savin et al. (Savin et al., 2010) in rats' blood at the combined action of stem cells and multiple MMW exposure (30 $\mathrm{min} /$ day, 6 days, and $37.7 \mathrm{GHz}$ ). Ovoshchnikova et al. (Ovoshchnikova et al., 2001) studied EHF EMI and $\gamma$-radiation combined effects in the blood and brain of rats. The $\gamma$-radiation was applied to the upper thoracic vertebrea and to the zone of the pelvic bone, after which the whole body EMI of animals took place. It has been revealed that certain frequencies from the $53.57-78.33 \mathrm{GHz}$ band $\left(0.2-1.5 \mathrm{~W} / \mathrm{cm}^{2}\right)$ effectively changed the conjugated dienes content up to $30 \%$ in blood, and in the brain the same parameter increased about 1.5 times.

There are numerous animal studies that have shown various examples of how microwave (SHF EMI) induce ROS and changes in antioxidant enzymes activity in blood, brain, kidneys and other organs (Kesari et al., 2011; Kesari et al., 2012; Bodera et al., 2015).

To the best of our knowledge, there are only few reports on the investigation into the EHF EMI effects on lipid peroxidation in different tissues of rats. Also, the results of previous studies on the effects of EHF EMI on lipid peroxidation are still contradictory (Sharov et al., 1983; Logani, Ziskin, 1996; Bodera et al., 2015). Due to this issue, the present study was aimed to investigate the effects of 42.2 and $50.3 \mathrm{GHz}$ MMW frequencies on the lipid peroxidation in different organs of whole body exposure rats.

\section{MATERIAL AND METHODS}

\section{Animals}

Experiments were performed on 30 Wistar male rats with $100-120 \mathrm{~g}$ body weight. In order to adapt to temperature, humidity, and to the reg- ular light (12 h)/dark (12 h) cycle, the animals were stored for one week in animal laboratory before EHF EMI exposure. The temperature was set at $21^{\circ} \mathrm{C}$ and food and water were always available ad libitum. All experiments were performed between 9.00 a.m. and 4 p.m., and EMI exposure was carried out at a fixed time - within 9.00 and 10.00 a.m.

\section{Ethics}

All performed experiments and procedures were in accordance with the guidelines for animal care and ethical standards laid down in the 1964 Declaration of Helsinki and its later amendments.

\section{Experimental procedure}

Animals were allocated into three groups of equal number of rats in each one (ten) as follows:

1. Sham exposure - animals underwent the same manipulations, but were sham-exposed.

2. Experimental group l included rats exposed to the EMI with $42.2 \mathrm{GHz}$ frequency $20 \mathrm{~min} /$ day, 5 days, total exposure duration $100 \mathrm{~min}$.

3. Experimental group 2 included rats exposed to the EMI with $50.3 \mathrm{GHz}$ frequency $20 \mathrm{~min} /$ day, 5 days, total exposure duration $100 \mathrm{~min}$.

Exposure took place in a $150 \mathrm{~mm} \times 100 \mathrm{~mm}$ $\times 70 \mathrm{~mm}$ ventilated Plexiglas container. Animals were irradiated without fixing at a room temperature $(21 \pm 1.0)^{\circ} \mathrm{C}$ in frequency-modulated oscillating mode, $20 \mathrm{~cm}$ away from waveguide.

The irradiation was performed using the monochromatic EMI generator G4-141 type with working interval of $37.50-53.57 \mathrm{GHz}$ (State Scientific-Production Enterprise "Istok", Russia). EMI frequencies used were 42.2 and $50.3 \mathrm{GHz}$ and power flux density $-0.06 \mathrm{~mW} . \mathrm{cm}^{-2}$. Frequency deviation of output signal in persistent regime of generation did not exceed $6 \mathrm{MHz}$. The whole body specific absorption rate (SAR) was estimated to be $0.14 \mathrm{~W} / \mathrm{kg}$.

After completion of the exposure period, rats were sacrificed immediately, after anaesthesia with diethyl ether. Whole brain, liver, heart and the skeletal muscle from the right hind paw from control and test rats, were isolated, washed in saline, dried with filter paper, cleaned of fat and fibrous tissue. A cut section 
was weighted and stored frozen at $-4^{\circ} \mathrm{C}$ for subsequent malondialdehyde (MDA) determination as soon as possible.

\section{Lipid peroxidation}

Lipid peroxidation in rats' tissues was determined by estimation of the final product of LPO-malondialdehyde (MDA) content following the method of Stalnaya (Stalnaya, Garishvili, 1985).

Samples of tissues were homogenized using the homogenizer Karl Kolb (Scientific Technical Supplies, Germany). The homogenization ice-cold buffer ( $\mathrm{pH} 7.5$ ) consisted of $0.25 \mathrm{mM}$ Tris- $\mathrm{HCl}, 0.32 \mathrm{mM}$ sucrose, $0.5 \mathrm{mM}$ ethylendiamine tetra-acetic acid (EDTA), and $0.175 \mathrm{mM}$ $\mathrm{KCl} ; 1 \mathrm{ml}$ buffer was added for each $0.1 \mathrm{~g}$ of tissue. After homogenization, the samples were centrifuged at $3000 \times \mathrm{g}$ for $10 \mathrm{~min}$.

To every $1 \mathrm{ml}$ of supernatant, $1 \mathrm{ml}$ of mixture containing $17 \%$ trichloracetic acid (TCA), $0.25 \mathrm{M} \mathrm{HCl}$ and $0.5 \%$ thiobarbituric acid (TBA) was added. The samples was heated at $95^{\circ} \mathrm{C}$ for 20 min and then cooled quickly on an ice bath. The resulting mixture was centrifuged at $4000 \times \mathrm{g}$ for $15 \mathrm{~min}$. The absorbance of the supernatant was taken at $532 \mathrm{~nm}$ using UV-visible Spectrophotometer (model SF-46, USSR). The concentration of MDA was calculated by using the extinction coefficient of $1.56 \times 10^{5} \mathrm{M}^{-1} \mathrm{~cm}^{-1}$ and expressed as $\mathrm{nmol} / \mathrm{mg}$ protein.

The method of Lowry (Lowry, 1951) was followed to estimate the protein content in the tissues using bovine serum albumin as a standard.

\section{Statistical analysis}

For quantitative analysis results are represented as means \pm standard deviation. One-way analysis of variances method was adopted for statistical analysis. A value of $p<0.05$ indicated significance.

\section{RESULTS AND DISCUSSION}

The effect of EMI EHF on MDA-level at the multiple irradiation of 42.2 and $50.3 \mathrm{GHz}$ frequencies in different organs of rats was studied.

The obtained data showed that EMI results in increase lipid peroxidation process activity, which is expressed by an increasing MDA rate. It is obvious from the data in Table and in Fig. 1 that.

Table. Change in malondialdehyde content (nmol/mg protein) in different organs of EMI-exposed rats

\begin{tabular}{|c|c|c|c|c|c|c|c|c|c|c|c|}
\hline \multirow{2}{*}{$\begin{array}{c}\text { EMI fre- } \\
\text { quency } \\
\text { Expo- } \\
\text { sure } \\
\text { duration }\end{array}$} & \multirow{2}{*}{$\begin{array}{c}\text { Sham } \\
\text { expo- } \\
\text { sure } \\
0\end{array}$} & \multicolumn{5}{|c|}{$42.2 \mathrm{GHz}$} & \multicolumn{5}{|c|}{$50.3 \mathrm{GHz}$} \\
\hline & & $20 \mathrm{~min}$ & $40 \mathrm{~min}$ & $60 \mathrm{~min}$ & $80 \mathrm{~min}$ & $100 \mathrm{~min}$ & $20 \mathrm{~min}$ & $40 \mathrm{~min}$ & $60 \mathrm{~min}$ & $80 \mathrm{~min}$ & $100 \mathrm{~min}$ \\
\hline \multirow[t]{2}{*}{ Brain } & $\begin{array}{c}442.0 \pm \\
12.6\end{array}$ & $\begin{array}{c}443.0 \pm \\
12.3\end{array}$ & $\begin{array}{c}464.0 \pm \\
13.0\end{array}$ & $\begin{array}{c}486.0 \pm \\
14.0\end{array}$ & $\begin{array}{c}499.0 \pm \\
13.8\end{array}$ & $\begin{array}{c}494.0 \pm \\
15.8\end{array}$ & $\begin{array}{c}443.0 \pm \\
12.4\end{array}$ & $\begin{array}{c}467.0 \pm \\
13.6\end{array}$ & $\begin{array}{c}487.0 \pm \\
16.6\end{array}$ & $\begin{array}{c}515.0 \pm \\
18.2\end{array}$ & $\begin{array}{c}508.0 \pm \\
15.3\end{array}$ \\
\hline & $\mathrm{P}$ & NS & $<0.05$ & $<0.05$ & $<0.002$ & $<0.002$ & NS & $<0.005$ & $<0.005$ & $<0.001$ & $<0.001$ \\
\hline \multirow[t]{2}{*}{ Liver } & $\begin{array}{c}307.0 \pm \\
7.8\end{array}$ & $\begin{array}{c}308.0 \pm \\
7.6 \\
\end{array}$ & $\begin{array}{c}316.0 \pm \\
8.0\end{array}$ & $\begin{array}{c}331.0 \pm \\
8.8 \\
\end{array}$ & $\begin{array}{c}332.0 \pm \\
9.2 \\
\end{array}$ & $\begin{array}{c}329.0 \pm \\
8.6\end{array}$ & $\begin{array}{c}301.0 \pm \\
7.8 \\
\end{array}$ & $\begin{array}{c}323.0 \pm \\
8.4 \\
\end{array}$ & $\begin{array}{c}335.0 \pm \\
9.2 \\
\end{array}$ & $\begin{array}{c}348.0 \pm \\
9.4 \\
\end{array}$ & $\begin{array}{c}337.0 \pm \\
9.0\end{array}$ \\
\hline & $\mathrm{P}$ & NS & NS & $<0.05$ & $<0.002$ & $<0.002$ & NS & $<0.05$ & $<0.002$ & $<0.001$ & $<0.005$ \\
\hline \multirow[t]{2}{*}{ Heart } & $\begin{array}{c}170.0 \pm \\
4.0 \\
\end{array}$ & $\begin{array}{c}170.0 \pm \\
3.8 \\
\end{array}$ & $\begin{array}{c}171.0 \pm \\
4.2 \\
\end{array}$ & $\begin{array}{c}172.0 \pm \\
4.2 \\
\end{array}$ & $\begin{array}{c}172.0 \pm \\
4.6 \\
\end{array}$ & $\begin{array}{c}170.0 \pm \\
3.5 \\
\end{array}$ & $\begin{array}{c}171.0 \pm \\
4.2 \\
\end{array}$ & $\begin{array}{c}172.0 \pm \\
4.2 \\
\end{array}$ & $\begin{array}{c}171.0 \pm \\
4.4 \\
\end{array}$ & $\begin{array}{c}173.0 \\
4.6 \\
\end{array}$ & $\begin{array}{c}171.0 \pm \\
4.6 \\
\end{array}$ \\
\hline & $\mathrm{P}$ & NS & NS & NS & NS & NS & NS & NS & NS & NS & NS \\
\hline \multirow[t]{2}{*}{ muscle } & $\begin{array}{c}214.0 \pm \\
5.2 \\
\end{array}$ & $\begin{array}{c}214.0 \pm \\
5.3 \\
\end{array}$ & $\begin{array}{c}216.0 \pm \\
5.4 \\
\end{array}$ & $\begin{array}{c}218.0 \pm \\
6.1 \\
\end{array}$ & $\begin{array}{c}221.0 \pm \\
6.0 \\
\end{array}$ & $\begin{array}{c}219.0 \pm \\
5.8 \\
\end{array}$ & $\begin{array}{c}215.0 \pm \\
5.3 \\
\end{array}$ & $\begin{array}{c}220.0 \pm \\
5.3 \\
\end{array}$ & $\begin{array}{c}224.0 \pm \\
5.4 \\
\end{array}$ & $\begin{array}{c}226.0 \pm \\
5.4 \\
\end{array}$ & $\begin{array}{c}224.0 \pm \\
5.3 \\
\end{array}$ \\
\hline & $\mathrm{P}$ & NS & NS & NS & NS & NS & NS & NS & $<0.05$ & $<0.05$ & $<0.05$ \\
\hline
\end{tabular}

Values are expressed as mean in \pm SE. P - significance by LSD at $P<0.05$ from sham exposure group; NS - not significant. 


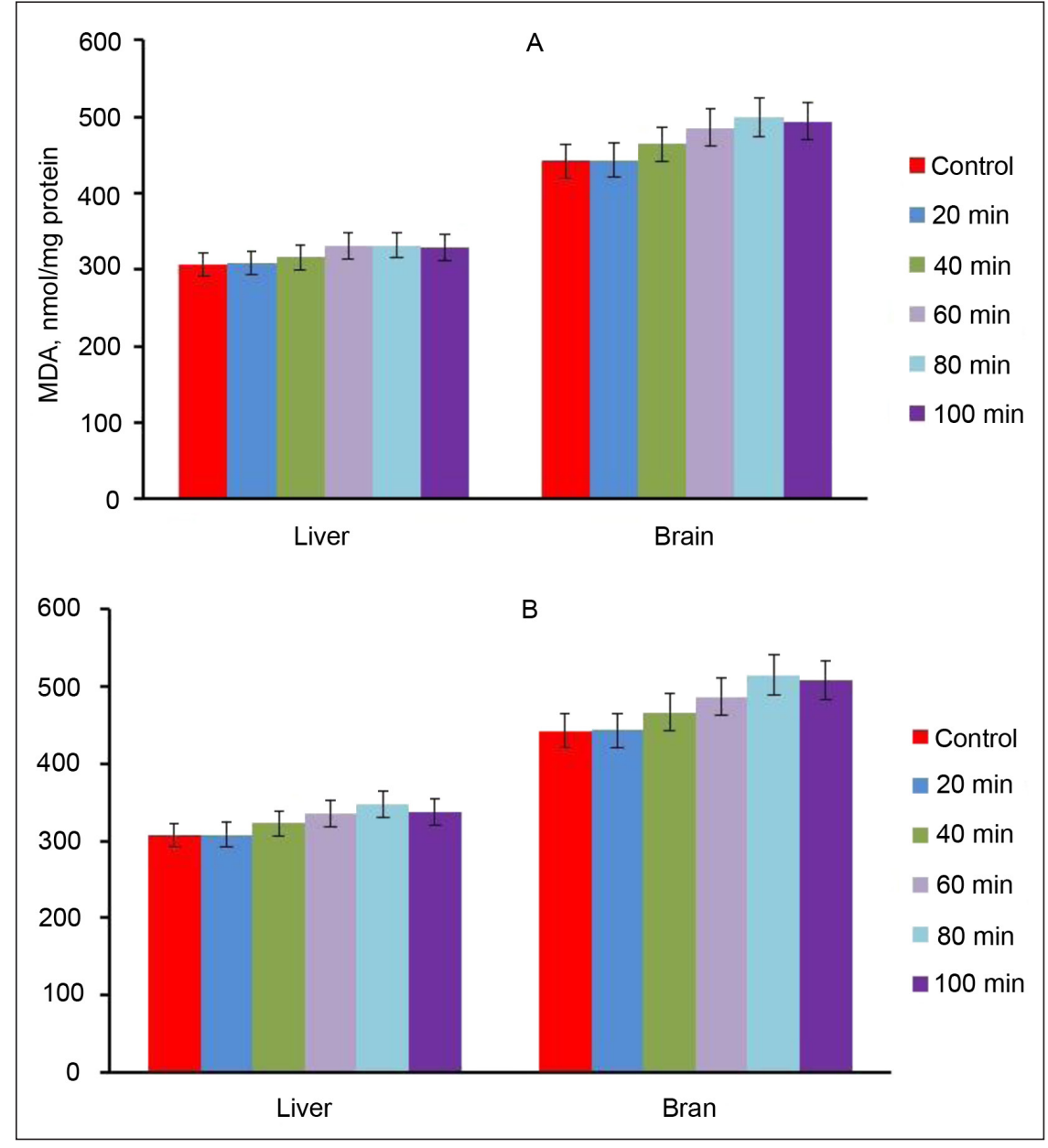

Fig. 1. The change in MDA production rate in liver and brain of rats after EMI of $42.2 \mathrm{GHz}(\mathrm{A})$ and $50.3 \mathrm{GHz}$ (B) frequencies. The rats were exposed to EMI as described in the "Materials and methods" section. The number of replicates was 4 . The vertical bars represent standard errors
The MDA level differs among the studied organs of the intact rats. Thus, the highest rate of a given parameter was recorded in brain (442 $\pm 12.6 \mathrm{nmol} / \mathrm{mg}$ protein), which exceeded the liver MDA rate $(307 \pm 7.8 \mathrm{nmol} / \mathrm{mg}$ protein) by 1.4 times and the heart and skeletal muscles rate by 2.6 and 2.0 times, respectively.

Lipid peroxidation is a normal physiological process that takes place in all aerobic cells of different tissues. The molecular mechanisms of the LPO process are known and it can be estimated that about $1 \%$ of the total oxygen uptake of cells, organs and bodies is taken up by reactions of LPO (Halliwel, Gutteridge, 1999). The obtained results may be connected with the quantitative and qualitative differences in lipid composition of cellular membranes of biological tissues (Halliwel, Gutteridge, 1999; Boveris, Navarro, 2008).

As seen in Fig. 1, in rats exposed to EMI of 42.2 and $50.3 \mathrm{GHz}$ frequencies, the values of MDA increased only in the brain and liver compared to the controls. It should be noted that values of the change depend on exposure duration: with an enhancement of influence duration, the dependence on the EMI frequency is revealed as well (Fig. 2). In brain and liver of $50.3 \mathrm{GHz}$ exposure rats, the increases of the MDA-rate are more pronounced than in those exposed to $42.2 \mathrm{GHz}$. Thus, 20 min irradiation invokes no changes of the MDA rate in any of the organs. After summary 100 min irradiation by $42.2 \mathrm{GHz}$, the value of MDA increases slightly in the liver within 3-8\% (Fig. 2). In the case of brain, the same frequency increased the MDA rate by $5 \%$ after $40 \mathrm{~min}$ irradiation, compared to controls, by $10.11 \%$, after $60 \mathrm{~min}$, by $13.2 \%$ after $80 \mathrm{~min}$, and by $12.0 \%$ after $100 \mathrm{~min}$.

After $40 \mathrm{~min}$ of $50.3 \mathrm{GHz}$ irradiation of rats, the value of MDA in the brain increased by $6.1 \%$, by $10.8 \%$ after $60 \mathrm{~min}$, by $16.3 \%$ after $80 \mathrm{~min}$, and by $15.2 \%$ after $100 \mathrm{~min}$ of irradiation. 


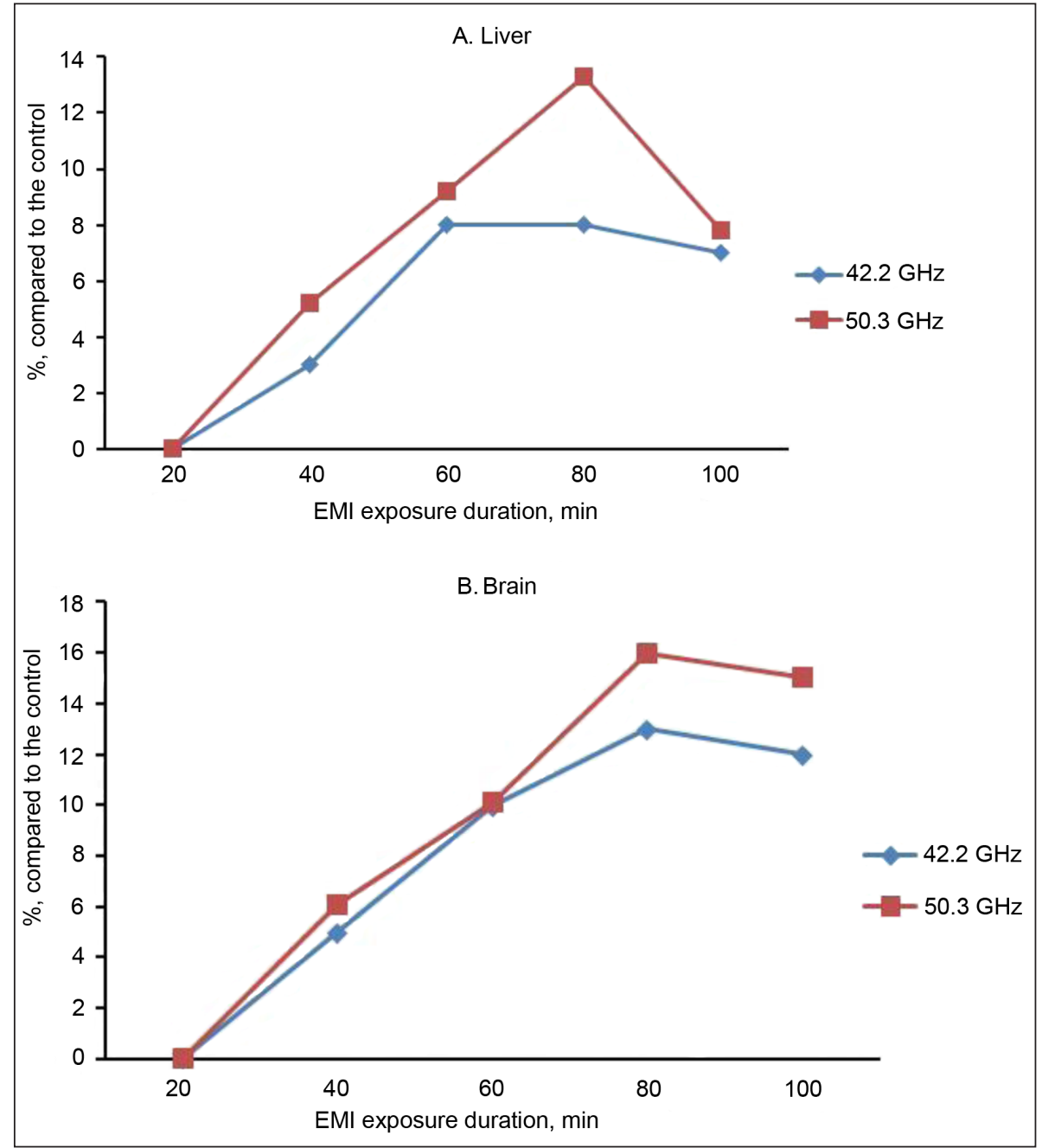

Fig. 2. The dependence of the value of the MDA content changes (\%, compared to the controls) in liver (A) and brain (B) of rats exposed to EMI at frequencies of $42.2 \mathrm{GHz}$ and $50.3 \mathrm{GHz}$ on multiple exposure duration (min).

The MDA concentration remained at the same level in the skeletal and especially in the cardiac tissue in EMI-treated rats.

The problem of medico-ecological consequences of EHF EMI has emerged as an important field of research in recent decades as a result of the increased number of non-natural EMI sources.

The majority of in vivo experiments concerning the influence of electromagnetic field exposure on the activity of the lipid peroxidation process have been conducted on laboratory rodents (Ovoshchnikova et al., 2001; Devrim et al., 2008; Savin et al., 2010; Kesari et al., 2012; Bodera et al., 2015). Highly variable results were obtained in studies on the effects of EHF EMI. The increase in the MDA level in the brain and liver under the EMI stress in our study is consistent with the stud- ies conducted by other researchers (Savin et al., 2010; Kesari et al., 2012; Bodera et al., 2015). The significant increase of the MDA content in the brain encountered in the $50.3 \mathrm{GHz}$ EMIexposed group of the present study probably points, to the limits of the antioxidants of the neural tissue to cope with an excessive generation of MDA due to the EHF EMI exposure.

It can be concluded that increased levels of peroxidation in the brain and liver due to EMI radiation might play a role in inducing oxidative damage. The risk of the oxidative stress in various organs and possible health implications of such an exposure should be taken into account.

Received 18 July 2017 Accepted 8 September 2017 


\section{References}

1. Betskii O, Kislov V, Lebedeva N. [Millimeter Waves and living systems.] Moscow: Sciencepress; 2004. Russian.

2. Betskii O, Lebedeva N. Low-intensity millimeter waves in biology and medicine. In: Clinical application of Bioelectromagnetic Medicine. New York: Marcel Dekker, Inc.; 2004.

3. Bodera P, Stankewicz W, Ankowiak B, Paluch $\mathrm{M}$, et al. Influence of electromagnetic field $(1800 \mathrm{MHz})$ on lipid peroxidation in brain, blood, liver and kidney in rats. Int J Occup Med Environ Health. 2015; 28(4): 751-9.

4. Boveris A, Navarro A. Brain mitochondrial dysfunction in aging. Life. 2008; 60(5): 308-14.

5. Cojocaru A, Cojocaru N, Burkovetskya Zh. Mechanisms of water-mediated action of weak radio-frequency electromagnetic radiation on biological objects. Biophysics. 2005; 50: 141-56.

6. Devrim E, Erguder I, Durak I. Effects of electromagnetic radiation use on oxidant/antioxidant status and dna turn-over enzyme activities in erythrocytes and heart, kidney, liver and ovary tissues from rats; possible protective role of vitamin C. Toxicol Mech Methods. 2008; 18(9): 679-83.

7. Halliwel B, Gutteridge J. Free radicals in biology and medicine. New York: Oxford University Press; 1999.

8. Kesari K, Kumar S, Behari J. Phatophysiology of microwave radiation: effect on rat brain. Appl Biochem Biotechnol. 2012; 166(2): 379-88.

9. Kesari K, Kumar S, Behari J. 900-MHz microwave radiation promotes oxidation in rat brain. Electromagn Biol Med. 2011; 30(4): 219-24.

10. Logani K, Ziskin M. Continuous millimeterwave radiation has no effect on lipid peroxidation in liposomes. Radiat Res. 1996; 145(2): 231-5.

11. Lowry O, Reserbrough N, Farr S, Rondall R. Protein measurement with Folin phenol reagent. J Biol Chem. 1951: 193; 265-75.
12. Martinyuk V, Temur'yants N. [The role of lipid peroxidation and thiolsulfhydryl metabolism in antistressal effects of EHF EMI]. Millimetrovye volny v biologii i meditsine. 1995; 5: 61-9. Russian.

13. Moustafa Y, Moustafa R, Belacy A, Abou-ElEla $S$, et al. Effects of acute exposure to the radiofrequency fields of cellular phones on plasma lipid peroxide and antioxidase activities in human erythrocytes. J Pharm Biomed Anal. 2001; 26(4): 605-8.

14. Ongel K, Gumral N, Ozguner F. The potential effects of electromagnetic field: a review. Cell Membranes and Free Radical Research. 2009; 1(3): 85-9.

15. Ovoshchnikova L, Koryagin L, Eliseeva L. [Influence of EHF EMI on the blood system and lipid peroxidation at the experimental radiation disease]. Vestnik Nizhegorodskogo gosudarstvennogo universiteta im. N.I. Lobachevskogo. Biologiya, 2(4). Millimetrovyje volny v biologii i medicine. Nizhny Novgorod: Izdatelstvo NNGU; 2001; 2(4): 31-4. Russian.

16. Pakhomov AG, Akyel Y, Pakhomova ON, Stuck BE Murphy MR. Current state and implications of research on biological effects of millimeter waves: a review of the literature. Bioelectromagnetics, 1998; 19: 393-413.

17. Potselueva M, Pustovidko A, Chramov R, Chaylakhyan L. [Formation of oxygen reaction species in aquae solutions under EHF EMI]. DAN SSSR: 1998; 359(3): 468-476. Russian.

18. Ramundo-Orlando A. Effects of millimeter waves radiation on cell membrane - a brief review. J Infrared Millim Te. 2010; 31: 1400-11.

19. Repetto M, Ossani G, Monserrat A. Oxidative damage: the biochemical mechanism of cellular injury and necrosis in choline deficiency. Exper And Mol Pathology. 2010; 88: 143-9.

20. Savin E, Khadarsev A, Ivanov D, Subbotina T, et al. [Regulation of Free Radical processes by modulated action of electromagnetic irradiation in combination with stem cells]. Int J Appl and Fund Res. 2010; 5: 77-9. Russian. 
21. Sharov V, Kazarinov K, Andreev W, Putvinskii A, et al. [Acceleration of lipid peroxidation by MM-wave electromagnetic irradiation influence]. Biofizika. 1983; 28: 423-7. Russian.

22. Sinitsyn N, Pertosyan V, Yolkin V. Devyatkov N, et al. Special function of the "millimeter wavelength waves-aqueous medium" system in nature. Crit Rev Biomed Eng. 2000; 28(12): $29-41$.

23. Stalnaya I, Garishvili T. [Method of malondialdehyde dermination with tiobarbituric acid]. In: Stalnaya ID, Garishvili TG. Sovremennye metody v biokhimii. Moscow: Medicina, 1977, p. 66-68. Russian.

24. Torgomyan H, Trchounian A. Escherichia coli membrane associated energy-dependent processes and sensitivity toward antibiotics changes as responses to low-intensity electromagnetic irradiation of 70.6 and $73 \mathrm{GHz}$ frequencies. Cell Biochem Biophys. 2012; 62: 451-61.

25. Vecchia P, Matthes R, Ziegelberger G, Saunders R, et al., editors. Exposure to high frequency electromagnetic fields, biological effects and health consequences $(100 \mathrm{kHz}-$ $300 \mathrm{GHz}$ ). International Commission on NonIonizing Radiation Protection ICNIRP: 2009.

26. Vladimirov Yu, Archakov A. [Lipid's peroxidation in biological membranes]. Moscow: Nauka; 1972. Russian.

\section{Gayane Poghosyan, Marieta Mikaelyan,} Anahit Nerkararyan, Poghos Vardevanyan

\section{EKSTREMALIAI AUKŠTO DAŽNIO ELEK- TROMAGNETINĖS SPINDULIUOTĖS POVEI- KIS ŽIURKIŲ LIPIDŲ PEROKSIDACIJAI}

\section{Santrauka}

Labai aukšto dažnio ir mažo intensyvumo elektromagnetinè spinduliuotè (EMI) veikia gyvus organizmus skirtinguose struktūros lygmenyse, tačiau jos poveikio mechanizmas dar nèra visiškai aiškus. Šio tyrimo metu, apšvitinus visą žiurkès kūną, buvo tiriamas ekstremaliai aukšto dažnio elektromagnetinès spinduliuotès poveikis audinių lipidų peroksidacijai (LPO). Tyrimui naudoti Wistar žiurkių patinai penkias dienas buvo veikiami 42,2 ir $50,3 \mathrm{GHz}$ dažnio $\left(0,06 \mathrm{~mW} / \mathrm{cm}^{2}\right)$ EMI $20 \mathrm{~min}$. per dieną. Malondialdehido (MDA), kaip galutinio LPO produkto, kiekis buvo ivertintas žiurkių smegenyse, kepenyse, širdyje ir skeleto raumenyse. Pastebèta, kad priklausomai nuo dažnio ir poveikio trukmès EMI skirtinguose žiurkių organuose sukèlè oksidacini stresą. Labai aukšto dažnio EMI, taikyta keliais režimais, gerokai padidino lipidų peroksidacijos lygị smegenyse ir nedaug padidino kepenyse. Gauti duomenys rodo, kad toks poveikis gali sukelti smegenų pažeidimus.

Raktažodžiai: ekstremaliai aukšto dažnio elektromagnetinè spinduliuotè, oksidacinis stresas, lipidų peroksidacija, malondialdehidas, žiurkès 